INOBIS : Jurnal Inovasi Bisnis dan Manajemen Indonesia

Volume 03, Nomor 02, Maret 2020

Ibnu Lukman Pratama, Bambang Sugito, Laili Salsabila

\title{
Penempatan Ulang Material dan Perancangan Sistem Informasi Pengambilan Material Return Berbasis Web di Gudang PT ABC Unit Pembangkit X
}

\author{
*Ibnu Lukman Pratama \\ Politeknik Energi dan Mineral (PEM Akamigas) \\ Bambang Sugito \\ Politeknik Energi dan Mineral (PEM Akamigas) \\ Laili Salsabila \\ Politeknik Energi dan Mineral (PEM Akamigas) \\ *Ibnulukman_pratama@esdm.go.id
}

\begin{abstract}
Abstrak
Salah satu gudang di PT ABC UP X adalah Gudang Material Return. Material return adalah material yang dikembalikan ke gudang karena kelebihan atau sisa pemakaian dalam melaksanakan suatu pekerjaan atau hasil pembongkaran (bekas pakai). Tujuan dari penelitian ini adalah mengoptimalkan barang yang berada di gudang material return melalui aplikasi berbasis web dan mengajukan rancangan desain penempatan material yang lebih efisien. Hasilnya, dalam menentukan prioritas penempatan material, didapati bahwa material mekanik memiliki prioritas tertinggi dibandingkan material instrumentasi (prioritas nomor 2), material listrik (nomor 3) dan material umum. Selain itu berdasarkan dari ukuran material, material berukuran kecil memiliki frekuensi pengeluaran dan penerimaan lebih besar daripada material berukuran besar sehingga material berukuran besar dapat diletakkan jauh dari pintu gudang. Jika material ditata berdasarkan prioritas penempatan material dan ukuran material, maka terjadi prosentase penurunan jarak sebesar $17 \%$. Allowance dalam gudang tersebut minimal 4 meter. Untuk perancangan sistem informasi pegudangan memiliki 4 sistem yaitu admin, user, spv, dan pegawai umum. Setiap sistem memiliki menu yang berbeda. Saran dalam penelitian ini adalah diperlukan prosedur lebih lanjut untuk dilakukan pengecekan material yang jarang terpakai dan pengembangan aplikasi supaya dapat digunakan dalam berbagai aktivitas pergudangan.
\end{abstract}

Key Word: Gudang, Aplikasi Pergudangan, Layout, Sistem Informasi

\section{Pendahuluan}

Gudang merupakan bagian penting dalam sebuah perusahaan. Gudang adalah tempat penyimpanan yang dibebani tugas untuk menyimpan barang yang akan dipergunakan dalam produksi, sampai barang tersebut diminta sesuai jadwal produksi (Apple, James M, 1990). Gudang dapat digambarkan sebagai suatu sistem logistik dari sebuah perusahaan yang berfungsi untuk menyimpan produk dan perlengkapan produksi lainnya dan menyediakan informasi mengenai status serta kondisi material/produk yang disimpan di gudang sehingga informasi tersebut mudah diakses oleh siapa pun yang berkepentingan (Zaroni. 2015). Meskipun penting, namun adanya gudang tidak dapat dipisahkan dari sistem pergudangan. Pergudangan adalah suatu aktivitas menyimpan barang. Selain itu, pergudangan yang baik adalah pergudangan yang memiliki sistem pelayanan yang baik dan mencangkup adanya jaminan keamanan hingga kemudahan akses informasi keluar masuk (Warman, John. 2004). Tata letak gudang adalah suatu rancangan penempatan fasilitas, menganalisis, membentuk 
INOBIS : Jurnal Inovasi Bisnis dan Manajemen Indonesia

Volume 03, Nomor 02, Maret 2020

\section{Ibnu Lukman Pratama, Bambang Sugito, Laili Salsabila}

konsep, dan mewujudkannya dalam suatu sistem penerimaan sampai dengan pengiriman barang kepada pelanggan dengan meminimalkan total biaya yang mungkin terjadi (Widodo, Lamto, dkk. 2013)

Dalam melakukan pengaturan tata letak barang ada beberapa hal yang harus diperhatikan yaitu sistem pengukuran kecepatan yang baik dan sistem pengendalian yang baik. Sistem pengukuran kecepatan ini memperhatikan barang berdasarkan klasifikasi arus aliran barang yaitu slow moving, medium moving dan fast moving. Untuk slow moving ditempatkan di bagian yang sulit dijangkau karena barang tersebut jarang untuk dipesan atau akan berada di gudang dengan waktu yang cukup lama. Untuk barang medium moving ditempat di bagian tengah gudang yang cukup terjangkau. Sedangkan untuk barang fast moving ditempatkan di bagian yang mudah terjangkau agar dapat memudahkan dalam pengambilan barang sehingga efisiensi akan menjadi lebih tinggi. (William \& Sawyer. 2007)

Dalam sistem informasi logistik terdapat 3 subsistem utama yaitu Order Management System (OMS), Warehouse Management System (WMS), dan Transportation Management System (TMS). Ketiganya saling memiliki keterkaitan untuk mencapai tujuan masing-masing dalam sebuah sistem. Untuk mendukung manajemen pergudangan, salah satu dari tiga subsistem diatas yang digunakan yaitu Warehouse Management System (WMS). WMS adalah subsistem informasi yang membantu dalam pengelolaan produk yang mengalir melalui fasilitas-fasilitas dalam jaringan logistik dan yang tersimpan di fasilitas tersebut (Putri \& Marie. 2017). Tujuan utama dari WMS adalah untuk mengontrol pergerakan pemasukan, penyimpanan, dan pengambilan barang yang efisien dan efektif, serta kemudahan dan keakuratan informasi stok barang yang ada di gudang (Warman, John. 2004).

Salah satu gudang yang berada di PT ABC UP X adalah gudang material return. Material return adalah material bekas yang masih layak pakai atau layak repair sehingga dapat digunakan dalam kegiatan operasional. Material-material tersebut ditata berdasarkan fungsi dari material yang ada PT ABC UP X. Namun penataan saat ini masih menyulitkan user dalam mengambil barang. Hal tersebut dikarenakan banyaknya barang yang masih belum terdata dan belum ada pemberian kode penempatan barang berdasarkan peraturan PT ABC UP X. Selain itu proses administrasi untuk pengeluaran material di PT ABC UP $X$ belum terintegrasi menggunakan sistem online sehingga user tidak memiliki informasi mengenai status dan jumlah material.

Oleh karena itu, dibutuhkan suatu sistem informasi yang berguna untuk mengelola data material di gudang material return PT ABC UP X secara online. Selain itu diperlukan penentuan tata letak dan material handling yang tepat untuk pengoptimalan gudang supaya lebih efektif dan efisien serta tidak menghabiskan waktu pencarian material.

\section{Metode Penelitian}

Dalam penelitian ini, akan dilakukan dengan cara pertama kali yaitu konsep perancangan tata letak dimana terlebih dahulu mengetahui jenis material dan layout yang sedang berjalan. Data yang diperoleh adalah aktivitas penerimaan material, aktivitas penyimpanan material dan aktivitas pengeluaran material beserta dokumen-dokumen perusahaan yang berkenaan dengan masalah yang dibahas. Setelah itu membuat perancangan sistem informasi pengambilan material berbasis web. Berikut merupakan flow process implementasi konsep untuk perancangan tata letak dan flowchart perancangan aplikasi pergudangan. 
INOBIS : Jurnal Inovasi Bisnis dan Manajemen Indonesia Volume 03, Nomor 02, Maret 2020

Ibnu Lukman Pratama, Bambang Sugito, Laili Salsabila

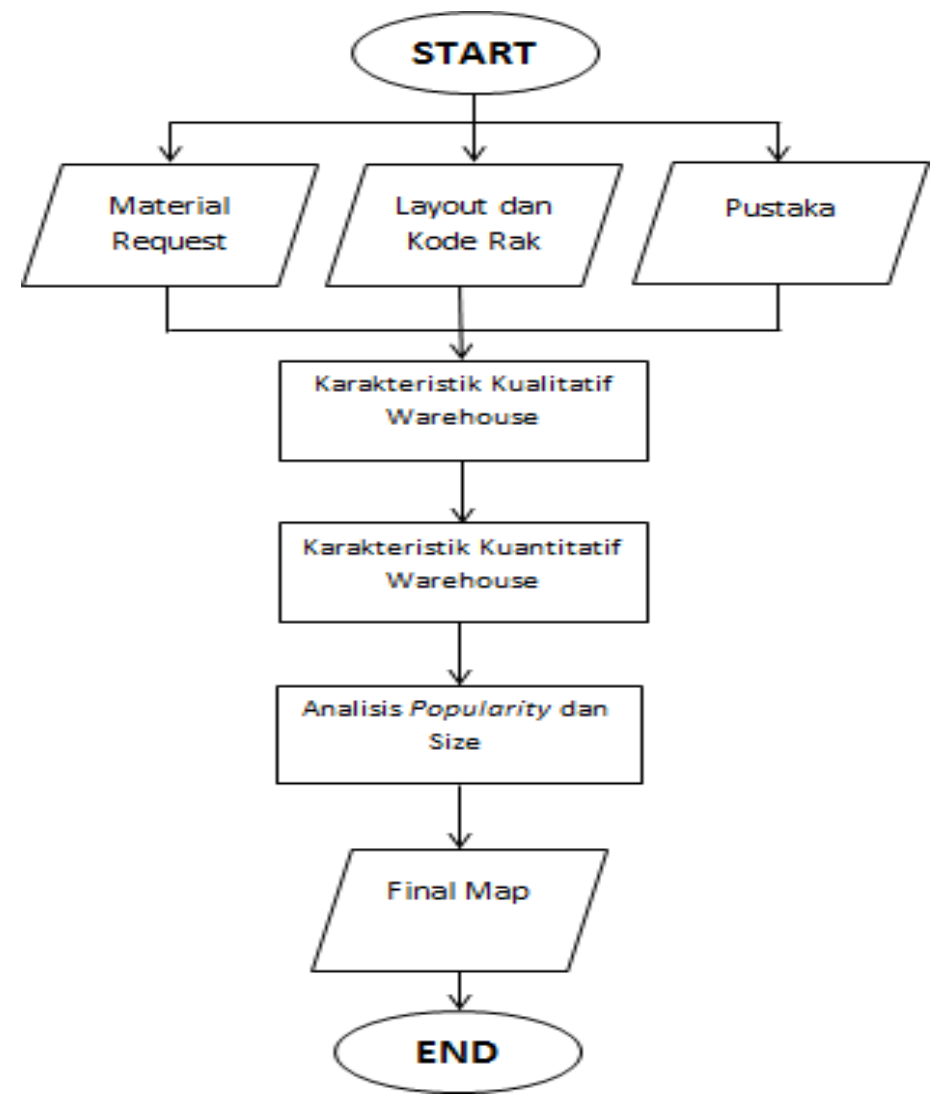

Gambar 1. Diagram Alir Konsep Perancangan Tata Letak

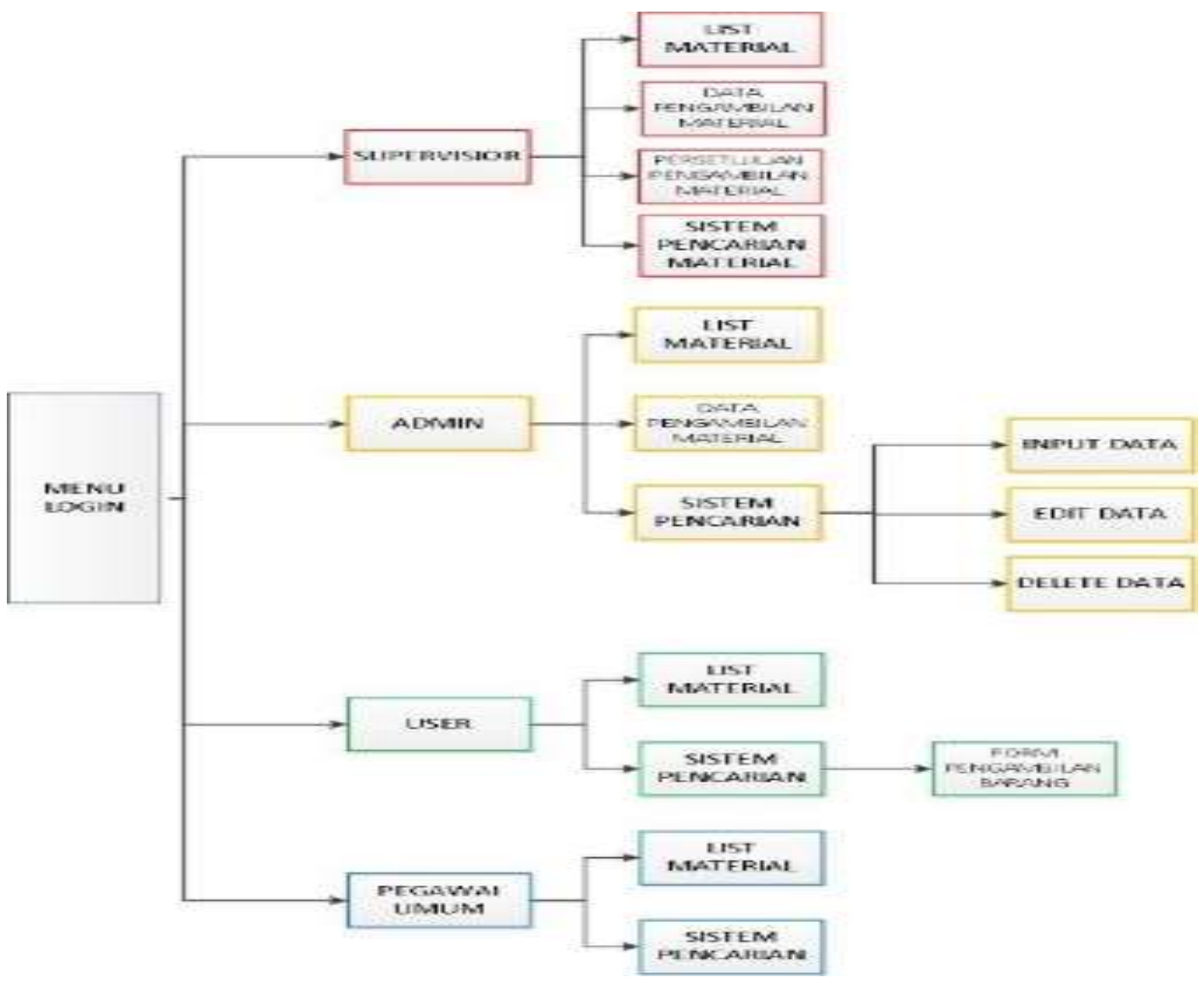

Gambar 2. Perancangan Aplikasi Pergudangan 
INOBIS : Jurnal Inovasi Bisnis dan Manajemen Indonesia

Volume 03, Nomor 02, Maret 2020

Ibnu Lukman Pratama, Bambang Sugito, Laili Salsabila

\section{Pembahasan}

Salah satu gudang yang terdapat di PT ABC UP X adalah gudang penyimpanan material return atau biasa disebut sebagai gudang 5/G-5. Gudang ini merupakan tempat dimana user dapat menyimpan atau mengambil sparepart bekas layak pakai dan repair yang diperlukan selama pemeliharaan dengan kondisi yang bagus dan sesuai spesifikasi. Barang-barang yang terdapat di gudang return dikarenakan berbagai alasan, antara lain :

1.Masih bisa digunakan, biasanya karena pemeliharaan faktor karakteristik. Misalnya, material A yang harus diganti karena penggunaannya sudah lebih dari 5000 jam.

2.Masih bisa direpair. Material-material yang masih bisa direpair biasanya karena barang tersebut mahal harga belinya/kerusakannya bukan kerusakan yang parah/untuk mendapatkan material yang baru memerlukan waktu yang lama.

3.Material gudang karena kelebihan atau sisa pemakaian dalam pelaksanaan suatu pekerjaan.

Gudang return seluas $25 \mathrm{~m}$ x $50 \mathrm{~m}$ x $7 \mathrm{~m}$ terdapat banyak sekali barang hingga tidak memungkinkan untuk adanya area receiving sehingga penerimaan material dilakukan di gudang inti (gudang administrasi). Material return akan dipindah ke gudang limbah jika sudah lebih dari 2 tahun dengan melakukan koordinasi lebih dahulu dengan user pemeliharaan.

Material return yang berukuran kecil di dalam gudang return diletakkan di dalam rak besi berukuran $10 \mathrm{~m}$ x 1,5 m x 3,5 m yang dikelompokkan berdasarkan jenis material yang beroperasi di PT ABC UP X. Untuk material return berukuran besar diletakkan di dalam gudang tanpa menggunakan rak.

Jika diidentifikasi lebih lanjut, terdapat beberapa waste yang ada dalam gudang material return ini. Antara lain :

1.Waiting : Saat material yang diinginkan user susah dicari, maka perlu waktu bagi petugas gudang untuk mencari material sehingga user perlu waktu menunggu untuk langkah proses selanjutnya. Hal tersebut merupakan salah satu adanya pemborosan yang tidak menambah nilai bagi perusahaan.

2.Motion : Saat material yang diinginkan user susah dicari, maka petugas perlu melakukan gerakan-gerakan yang tidak di perlukan seperti mencari-cari material yang ada di gudang. Hal tersebut juga merupakan salah satu kegiatan yang dapat dihindari.

3.Inventory : Saat material yang diinginkan user susah dicari dan petugas merasa tidak menemukan material tersebut, maka perlu diadakan pembelian lagi. Hal tesebut merupakan salah satu adanya pemborosan.

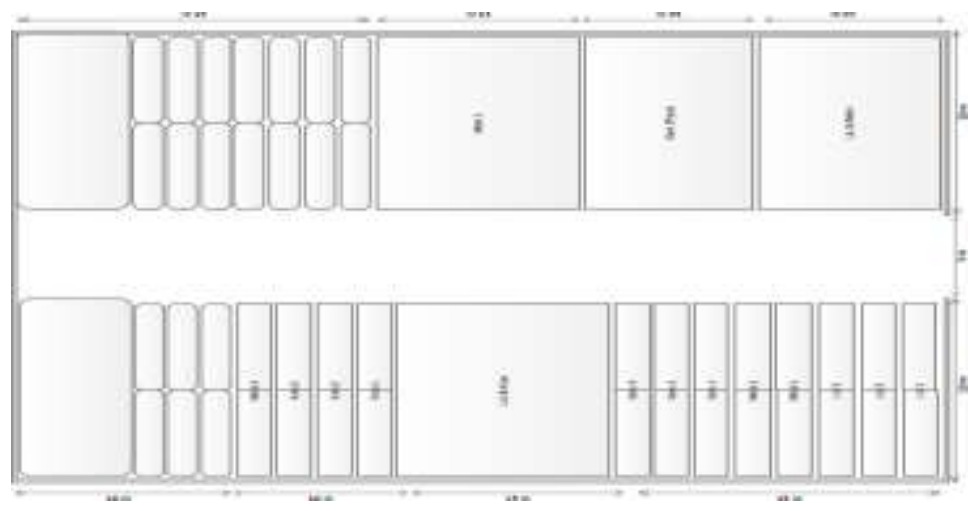

Gambar 3. Layout Gudang Material Return Saat Ini 
INOBIS : Jurnal Inovasi Bisnis dan Manajemen Indonesia

Volume 03, Nomor 02, Maret 2020

\section{Ibnu Lukman Pratama, Bambang Sugito, Laili Salsabila}

Material return yang berada di lantai tengah, lantai depan dan lantai belakang merupakan material return yang berukuran besar. Menurut data dan hasil wawancara, material yang diletakkan di lantai merupakan material yang dapat dikategorikan slow moving karena jarang adanya permintaan dari user.

Membahas mengenai proses operasional, secara umum terbagi atas penerimaan, penyimpanan material, dan pengeluaran material. Namun hal yang membedakan gudang return dengan gudang lain adalah proses yang digunakan masih menggunakan metode manual tanpa adanya sistem informasi yang terintegrasi.

Proses penerimaan material juga dapat dikatakan proses pengembalian material. Semua material yang telah dikeluarkan dari gudang bekas pakai hasil pembongkaran atau penggantian harus (wajib) dikembalikan ke gudang kecuali material consumable habis pakai. Bagian Perencanaan dan Pengendalian Pemeliharaan (Rendal) akan membuat bon pengembalian (return) barang kepada pihak gudang secara manual. Selanjutnya pihak gudang dan user akan melakukan pengecekan terhadap material yang dikembalikan termasuk jumlah dan kondisi material.

Proses Put Away adalah proses memindahkan material dari lokasi penerimaan menuju gudang yang sediakan. Setelah melakukan pemilahan dan pengkodean pada proses penerimaan material, dilakukan pelabelan terhadap material yang dikembalikan sebagai berikut :

- $\quad$ Label Merah : Status Barang Rusak

- $\quad$ Label Kuning : Status Barang Layak Repair

- $\quad$ Label Biru : Status Barang Layak Pakai

Jika barang rusak maka pihak gudang akan mengajukan lelang dengan cara memindahkan barang ke penampungan limbah dan mengajukan pelelangan barang ke pihak keuangan. Sementara untuk barang bisa pakai/ bagus maka pihak gudang akan menyimpan ke gudang return sesuai dengan unit yang mengembalikan. Berbeda dengan barang yang perlu di repair, jika tersedia jadwal untuk melakukan perbaikan maka akan dilakukan perbaikan dengan bidang yang berkaitan. Namun jika tidak ada jadwal perbaikan, maka barang akan disimpan di gudang sesuai dengan bidang yang berkaitan.

Aktivitas pemindahan ini menggunakan Forklift dengan kapasitas 2 atau 5 ton (tergantung dari berat material) dengan tinggi maksimal 6 meter (jika diperlukan). Aktivitas put away juga termasuk mencatat pada sistem berapa barang yang masuk.

Proses Penyimpanan (Storage Assignment) Material Return, secara umum, aktivitas penyimpanan dimulai dengan menentukan rak kosong, lalu dikelompokkan barang tersebut sesuai dengan bagian yang memberikan ke bagian gudang. Dalam gudang ini, penyimpanan material dibedakan berdasarkan jenis material yang ada di PT ABC UP dan ukuran dari material tersebut. Untuk material yang memiliki ukuran kecil maka perlu ditempatkan di dalam rak sementara untuk material berukuran besar diletakkan di atas lantai.

Proses pengeluaran barang dimulai dengan melakukan pengecekan terlebih dahulu apakah material yang dibutuhkan tersedia di gudang. Setelah dipastikan bahwa material yang dibutuhkan dapat digunakan, maka dibuatkan Bon Permintaan Barang secara manual ke gudang. Bon Permintaan Barang manual tersebut dibuat oleh user dan harus disetujui oleh atasan atau pejabat yang berwenang. Petugas gudang akan melayani sesuai dengan Bon Permintaan Barang yang telah diterbitkan oleh pihak gudang. Untuk mengetahui proritas material, maka perlu mengerti berapa frekuensi penerimaan dan pengeluaran material.

Penentuan jumlah penerimaan rata-rata per bulan perlu dilakukan sehingga dapat ditentukan fungsi apa yang banyak melakukan penerimaan dalam satu tahun 
INOBIS : Jurnal Inovasi Bisnis dan Manajemen Indonesia Volume 03, Nomor 02, Maret 2020

\section{Ibnu Lukman Pratama, Bambang Sugito, Laili Salsabila}

Tabel 1. Frekuensi Penerimaan Material Berdasarkan Jenis Barang

\begin{tabular}{|l|l|l|l|l|l|l|l|l|l|l|l|l|l|}
\hline & Jan & Feb & Mar & Apr & Mei & Jun & Jul & Agu & Sep & Okt & Nov & Des & Total \\
\hline Lis & 1 & 2 & - & 1 & - & - & 2 & 1 & 4 & 4 & 11 & 1 & 27 \\
\hline Ins & - & - & 1 & 1 & - & - & 3 & 3 & 1 & 9 & 3 & - & 21 \\
\hline Mek & 38 & - & - & 1 & 2 & 2 & 2 & - & 1 & 3 & 9 & 3 & 61 \\
\hline Gen & - & - & - & - & 1 & - & 2 & 1 & - & - & 20 & - & 24 \\
\hline
\end{tabular}

Pada frekuensi penerimaan material, material mekanik memiliki frekuensi paling banyak dalam waktu 1 tahun. Sementara, penentuan jumlah pengeluaran rata-rata per bulan perlu dilakukan sehingga dapat ditentukan fungsi apa yang banyak melakukan pengeluaran dalam satu tahun.

Tabel 2. Frekuensi Pengeluaran Material Berdasarkan Jenis Barang

\begin{tabular}{|l|l|l|l|l|l|l|l|l|l|l|l|l|l|}
\hline & Jan & Feb & Mar & Apr & Mei & Jun & Jul & Agu & Sep & Okt & Nov & Des & Tot \\
\hline Lis & 1 & 1 & 4 & 1 & - & - & - & - & 1 & 6 & 5 & 1 & 20 \\
\hline Ins & 2 & - & 1 & 2 & 6 & 4 & 2 & 1 & 6 & 3 & 2 & 2 & 33 \\
\hline Mek & 3 & 1 & 1 & 1 & 2 & - & - & - & 6 & 2 & 4 & 1 & 21 \\
\hline Gen & 2 & - & - & - & 3 & 1 & - & 1 & 1 & 3 & 2 & 2 & 15 \\
\hline
\end{tabular}

Pada frekuensi pengeluaran material, material instrumen memiliki frekuensi paling banyak dalam waktu 1 tahun. Penentuan prioritas penempatan produk untuk setiap cluster dilakukan dengan menghitung persentase T/S (throughput per storage). Penentuan prioritas penempatan material untuk setiap jenis dilakukan dengan menghitung. Throughput dihitung dengan menggunakan persamaan (1) (Tompkins, J. A., dkk. 2010) :

Throughput $(\mathrm{T})=($ frekuensi in $\mathrm{x}$ probabilitas in $)+($ frekuensi out $\mathrm{x}$ probabilitas out $)$

Tabel 3. Perhitungan Throughput (T) per Jenis Material

\begin{tabular}{|c|c|c|c|}
\hline No & Jenis Material & Perhitungan & Hasil \\
\hline 1 & Listrik & $\begin{array}{c}(27 \times 0,5)+(20 \times \\
0,5)\end{array}$ & 23,5 \\
\hline 2 & Kontrol & $\begin{array}{c}(21 \times 0,5)+(33 \times \\
0,5)\end{array}$ & 27 \\
\hline 3 & Mekanik & $\begin{array}{c}(61 \times 0,5)+(21 \times \\
0,5)\end{array}$ & 41 \\
\hline 4 & Umum & $\begin{array}{c}(24 \times 0,5)+(15 \times \\
0,5)\end{array}$ & 19,5 \\
\hline
\end{tabular}

Untuk storage (s), dapat dilihat pada gambar 3 tata letak gudang yang ada, terdapat 12 rak dengan pembagian seperti tersebut : 
INOBIS : Jurnal Inovasi Bisnis dan Manajemen Indonesia Volume 03, Nomor 02, Maret 2020

\section{Ibnu Lukman Pratama, Bambang Sugito, Laili Salsabila}

a. 3 rak yang digunakan untuk material Listrik

b. 3 rak yang digunakan untuk material Konin

c. 3 rak yang digunakan untuk material Mekanik

d. 3 rak yang digunakan untuk material Umum.

Sehingga untuk menentukan jenis material mana yang prioritas, dilakukan pembagian antara throughput dan storage.

Tabel 4. Nilai Prioritas Jenis Material

\begin{tabular}{|c|c|c|}
\hline No & Jenis Material & Hasil \\
\hline 1 & Listrik & 23,5 \\
\hline 2 & Kontrol Instrumen & 27 \\
\hline 3 & Mekanik & 41 \\
\hline 4 & Umum & 19,5 \\
\hline
\end{tabular}

Berdasarkan perhitungan di atas dapat dilihat bahwa jenis material mekanik memiliki nilai T/S paling besar sehingga rak untuk menyimpan material jenis mekanik diletakkan di dekat in dan out material. Selanjutnya terdapat rak kontrol instrumen dan yang paling belakang adalah listrik dan umum.

Pemanfaatan ruang gang atau allowance untuk menggerakkan material handling menggunakan forklift sebagai alat angkut produknya. Sehingga allowance yang dibutuhkan berdasarkan kebutuhan untuk jalur sesuai dengan ukuran dimensi forklift. Warehouse memiliki 1 buah forklift 3 Ton bermerk Toyota panjang 3,78 $\mathrm{m}$ dan lebar 1,24 $\mathrm{m}$ dan dihitung berdasarkan persamaan (2) (Noor, I. 2018)

$$
\begin{gathered}
\text { Diagonal }=\sqrt{\mathrm{p}^{2}+\mathrm{l}^{2}} \\
\begin{aligned}
\text { Diagonal }= & \sqrt{3,78^{2}+1,24^{2}} \\
= & 3,98 \approx 4
\end{aligned}
\end{gathered}
$$

Dengan mengetahui allowance yang dibutuhkan maka dapat ditentukan lebar gang yaitu minimal $4 \mathrm{~m}$. Penempatan area berdasarkan jenis produk yang memiliki rata-rata frekuensi tertinggi atau produk yang sering keluar didekatkan dengan pintu masuk-keluar. Jarak tempuh antara material handling adalah mulai dari pintu (I/O) menuju ke area penyimpanan perhitungan jarak dilakukan dengan menggunakan metode rectilinear distance. Jarak diukur sepanjang lintasan dengan menggunakan garis tegak lurus (ortogonal) satu dengan yang lainnya terhadap titik dari masing-masing area penyimpanan dengan menggunakan persamaan (3) (Purnomo Hari. 2004) :

$$
\begin{gathered}
\text { dij }=|x-a|+|y-b| \\
d 1.1=|x-a|+|y-b|=|0-9,25|+|0-5,125|=14,375 m \\
d 2.1=|x-a|+|y-b|=|0-3,95|+|0-5,125|=9,075 m
\end{gathered}
$$

dij $\quad=$ jarak slot ij ke titik $\mathrm{I} / \mathrm{O}$

$\mathrm{x}=$ titik awal perhitungan $\mathrm{I} / \mathrm{O}$ pada sumbu $\mathrm{x}$ (horizontal) $\mathrm{a}=$ jarak titik tengah tujuan terhadap sumbu $\mathrm{x}$ 
INOBIS : Jurnal Inovasi Bisnis dan Manajemen Indonesia

Volume 03, Nomor 02, Maret 2020

\section{Ibnu Lukman Pratama, Bambang Sugito, Laili Salsabila}

$\mathrm{y}=$ titik awal perhitungan I/O pada sumbu y (vertical) $\mathrm{b}=$ jarak titik tengah tujuan terhadap sumbu y

Tabel 5. Tabel Jarak Tempuh Pintu ke Area Penyimpanan Layout Awal

\begin{tabular}{|c|c|c|}
\hline No & Area Penyimpanan & Jarak $(\mathrm{m})$ \\
\hline 1 & Lis 1 & 8,75 \\
\hline 2 & Lis 2 & 10,75 \\
\hline 3 & Lis 3 & 12,75 \\
\hline 4 & Mek 1 & 14,75 \\
\hline 5 & Mek 2 & 16,75 \\
\hline 6 & Gen 1 & 18,75 \\
\hline 7 & Gen 2 & 20,75 \\
\hline 8 & Gen 3 & 22,75 \\
\hline 9 & Lis \& Kon & 31,5 \\
\hline 10 & Kon 1 & 40,25 \\
\hline 11 & Kon 2 & 42,25 \\
\hline 12 & Kon 3 & 44,25 \\
\hline 13 & Mek 3 & 46,25 \\
\hline 14 & Lis \& Mek & 12,25 \\
\hline 15 & Pipa & 22,5 \\
\hline 16 & Mek 1 Besar & 35 \\
\hline & Total & 555,5 \\
\hline
\end{tabular}

Berikut merupakan usulan layout penempatan material di gudang return berdasarkan prioritas penempatan material dan ukuran material

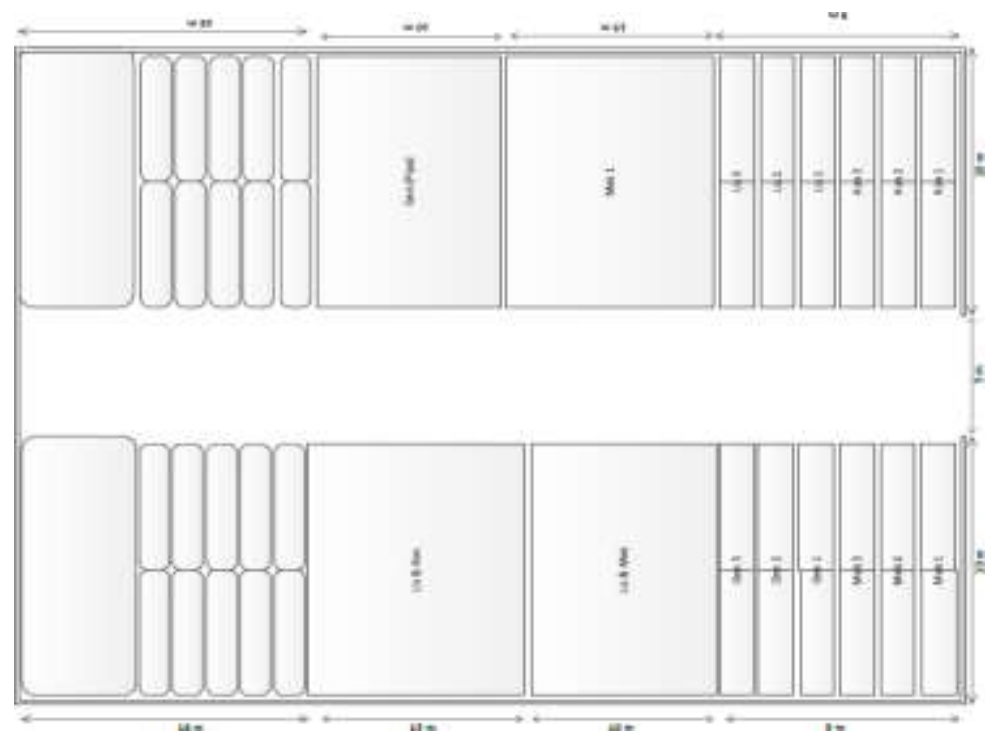

Gambar 4. Usulan Layout Gudang Material Return 
INOBIS : Jurnal Inovasi Bisnis dan Manajemen Indonesia Volume 03, Nomor 02, Maret 2020

\section{Ibnu Lukman Pratama, Bambang Sugito, Laili Salsabila}

Berdasarkan layout tersebut, material-material mandatory diletakkan di bagian dalam gudang sementara untuk material seperti konin dan listrik di letakkan di bagian depan gudang. Berikut merupakan perbandingan jarak antara layout awal dengan usulan layout baru :

Tabel 6. Perbandingan Jarak Tempuh Pintu ke Area Penyimpanan

\begin{tabular}{|c|c|c|c|}
\hline No & $\begin{array}{c}\text { Area } \\
\text { Penyimpanan }\end{array}$ & $\begin{array}{c}\text { Jarak } \\
\text { Layout } \\
\text { Lama }\end{array}$ & $\begin{array}{c}\text { Jarak } \\
\text { Layout } \\
\text { Baru }\end{array}$ \\
\hline 1 & Lis 1 & 8,75 & 13,25 \\
\hline 2 & Lis 2 & 10,75 & 14,75 \\
\hline 3 & Lis 3 & 12,75 & 16,25 \\
\hline 4 & Mek 1 & 14,75 & 8,75 \\
\hline 5 & Mek 2 & 16,75 & 10,25 \\
\hline 6 & Gen 1 & 18,75 & 13,25 \\
\hline 7 & Gen 2 & 20,75 & 14,75 \\
\hline 8 & Gen 3 & 22,75 & 16,25 \\
\hline 9 & Lis \& Kon & 31,5 & 33,75 \\
\hline 10 & Kon 1 & 40,25 & 8,75 \\
\hline 11 & Kon 2 & 42,25 & 10,25 \\
\hline 12 & Kon 3 & 44,25 & 11,75 \\
\hline 13 & Mek 3 & 46,25 & 11,75 \\
\hline 14 & Lis \& Mek & 12,25 & 21,25 \\
\hline 15 & Pipa & 22,5 & 36,25 \\
\hline 16 & Mek 1 Besar & 35 & 23,75 \\
\hline \multicolumn{7}{r|}{ Total } & 555,5 & 462 \\
\hline
\end{tabular}

Jika dilihat pada tabel diatas terdapat perbandingan jarak yang cukup signifikan. Jika dihitung menggunakan prosentase penurunan jarak dihitung berdasarkan persamaan (4):

$$
\begin{gathered}
\text { Prosentase Penurunan Jarak }=\frac{\text { Layout } \text { Lama-Layout Baru }}{\text { Layout Lama }} \times 100 \% \\
\frac{555,5-462}{555,5} \times 100 \%=17 \%
\end{gathered}
$$

Supaya lebih optimal, dilakukan pengecekan material setiap tahunnya kepada bagian operasional yang bersangkutan. Hal tersebut dilakukan untuk mengurangi material-material yang sudah tidak terpakai ke bagian limbah dan melakukan update material-material apa saja yang masih digunakan supaya pemanfaatannya lebih optimal. Sehingga dibutuhkan suatu program yang dapat merangkum data material apa saja yang ada di gudang return dan berapa lama matrial tersebut berada di gudang.

Aplikasi pergudangan gudang material return adalah program yang dibuat dengan tujuan untuk mendata seluruh material return yang ada di gudang serta memudahkan user untuk mencari dimana material tersebut disimpan. Aplikasi ini disusun oleh tiga komponen utama yaitu database MySQL, bahasa pemrograman berbasis PHP, dan bahasa pemrograman berbasis CSS. Aplikasi yang digunakan untuk pembuatan adalah Xamp v3.2.3 dan Notepad++.

Memiliki 1 database MySQL yang terdiri dari 3 tabel sebagai perekam data. Setiap database memiliki fungsi yang berbeda. 
INOBIS : Jurnal Inovasi Bisnis dan Manajemen Indonesia Volume 03, Nomor 02, Maret 2020

Ibnu Lukman Pratama, Bambang Sugito, Laili Salsabila

\begin{tabular}{|c|c|c|}
\hline Tabel - Tindakan & Baris of veris Pengortiran & Ukuran Beban \\
\hline 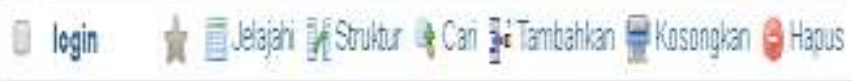 & $12 \mathrm{moCOB}$ kathl_suedish ci & $16: B$ \\
\hline 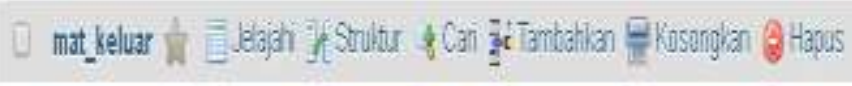 & 1 ImoOb kainl _rueish_o & 1618 \\
\hline 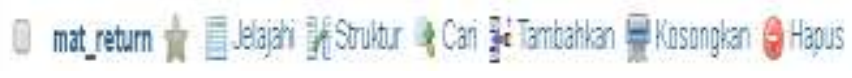 & 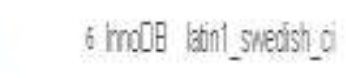 & $16 \times 8$ \\
\hline
\end{tabular}

Gambar 5. Database Aplikasi Pergudangan

Setiap tabel memiliki fungsi dan terdiri dari beberapa kolom sebagai berikut :

\section{A. Tabel Login}

Tabel login digunakan untuk menyimpan seluruh data username dan password yang memiliki hak akses terhadap aplikasi. Gambar adalah struktur tabel pada MySQL

\begin{tabular}{|c|c|c|c|c|c|c|c|c|}
\hline & $\nexists$ & Nama & Jenis & Penyortiran & Atribut Tak Ternilai & ai Brsaan Komentar & I Ekstra & Tindakan \\
\hline 日 & 1 & id $?$ & $\mathrm{rt}(11]$ & & Tdak: & Tuak adg & ANTO_ NCFENENT & 2ukah A Hapus $>$ Lamya \\
\hline 0 & 2 & username & varchan 225 & 6) latin1_svedish_a & Tdak & Thdak ads & & 2 Utah B Haous $\nabla$ Lamya \\
\hline 문 & 3 & password & varchar, 225 & I) lann1_svedish_a & Tdak: & Traktacta & & 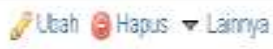 \\
\hline [] & 4 & status & test & latn1_svedsh_di & Todak & Tidak adt & & Q7. bah B Hapus $>$ Laima \\
\hline
\end{tabular}

Gambar 6. Struktur Tabel Login

B. Tabel mat_keluar

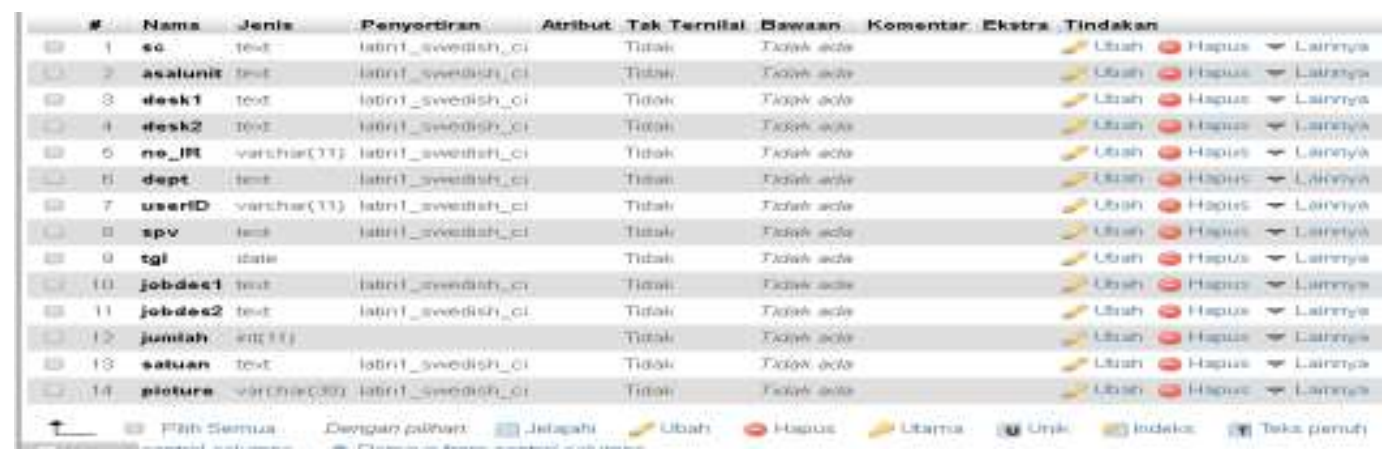

Gambar 7. Struktur Tabel Mat_Keluar

Tabel mat_keluar digunakan untuk menyimpan seluruh data material yang diambil oleh user 
INOBIS : Jurnal Inovasi Bisnis dan Manajemen Indonesia Volume 03, Nomor 02, Maret 2020

\section{Ibnu Lukman Pratama, Bambang Sugito, Laili Salsabila}

C. Tabel mat_return

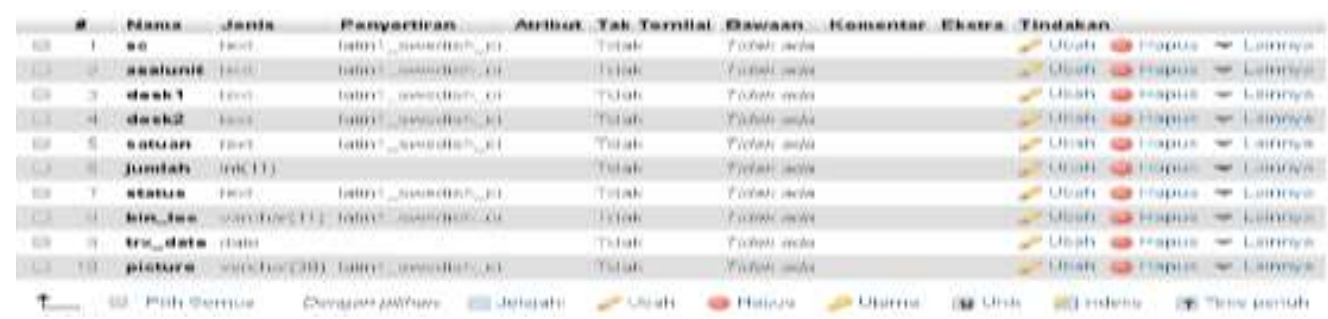

Gambar 8. Struktur Tabel Mat_Return

Tabel mat_return digunakan untuk menyimpan seluruh data material.

Aplikasi ini menggunakan bahasa pemrograman php untuk proses dan CSS untuk tampilan. Adapun coding untuk proses dihubungkan dengan tampilan menggunakan $\langle\mathrm{html}\rangle$. Berikut merupakan tampilan dari sistem informasi gudang material return :

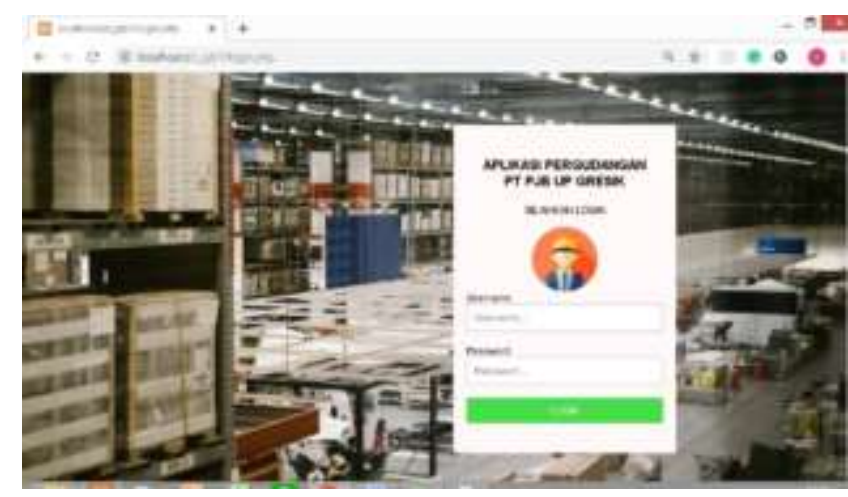

Gambar 9. Tampilan Login
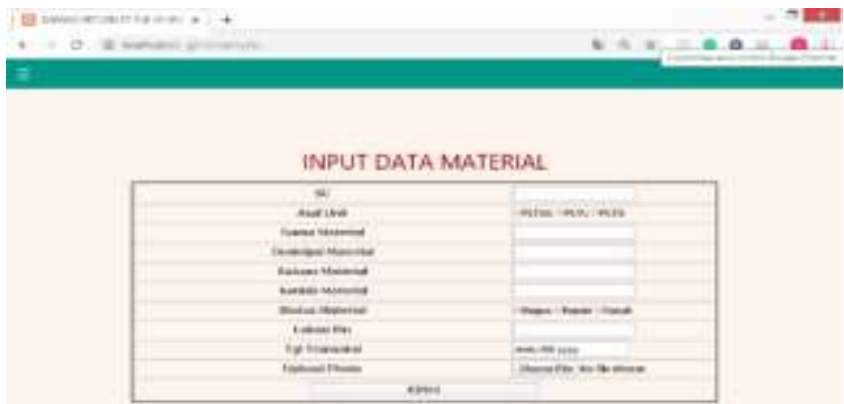

Gambar 10. Add Material Return

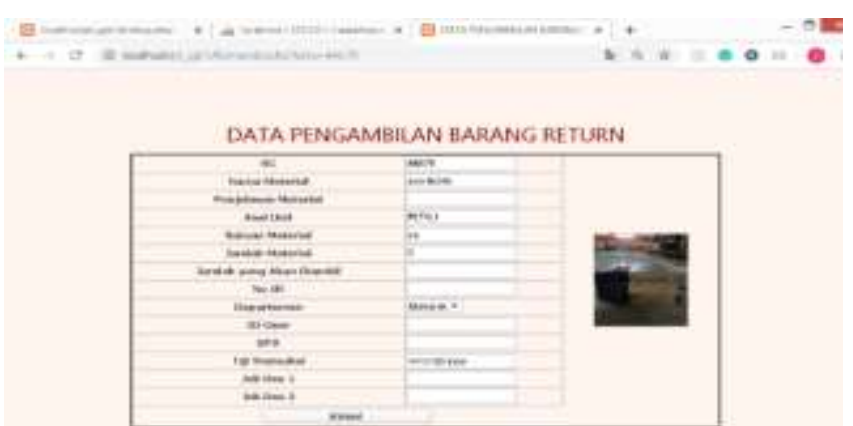

Gambar 11. Form Pengambilan Material Return 
INOBIS : Jurnal Inovasi Bisnis dan Manajemen Indonesia

Volume 03, Nomor 02, Maret 2020

\section{Ibnu Lukman Pratama, Bambang Sugito, Laili Salsabila}

Perbedaan antara sistem admin, user, spv, dan umum/anggota terletak pada menu utama yang ditampilkan. Admin memiliki hak untuk merubah data, sementara user hanya bisa mengakses jika akan mengambil material, spv bisa melihat list material dan histori pengambilan material untuk melakukan pengecekan, sementara anggota/umum dapat melihat list material yang ada di gudang.

Menu Utama akan berbeda jika diakses oleh bagian yang berbeda. Berikut merupakan perbedaan dari setiap sistem.
a. Home
b. List Material
c. Add Material
d. Edit Material
e. Delete Material
f. History Pengambilan Barang
g. Log Out

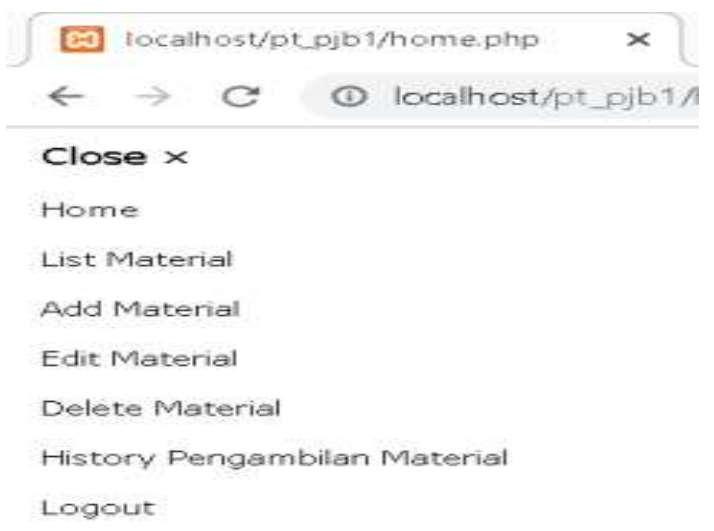

Gambar 12. Menu Admin

Berbeda jika diakses oleh user, maka menu utama menjadi sebagai berikut :
a. Home
b. Pengambilan Material
c. Log Out

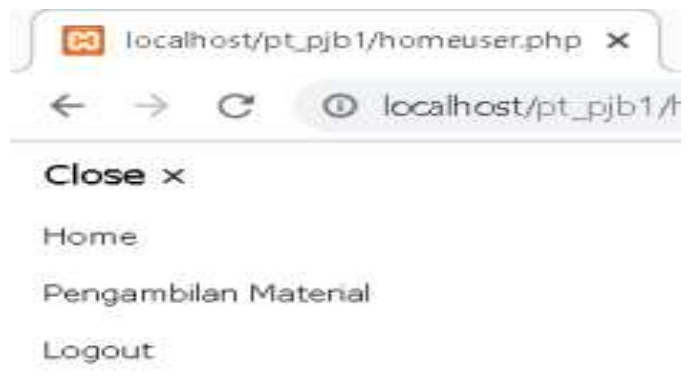

Gambar 13. Menu User 
INOBIS : Jurnal Inovasi Bisnis dan Manajemen Indonesia

Volume 03, Nomor 02, Maret 2020

Ibnu Lukman Pratama, Bambang Sugito, Laili Salsabila

Namun jika diakses oleh supervisor dan umum, maka menu utama akan menjadi :

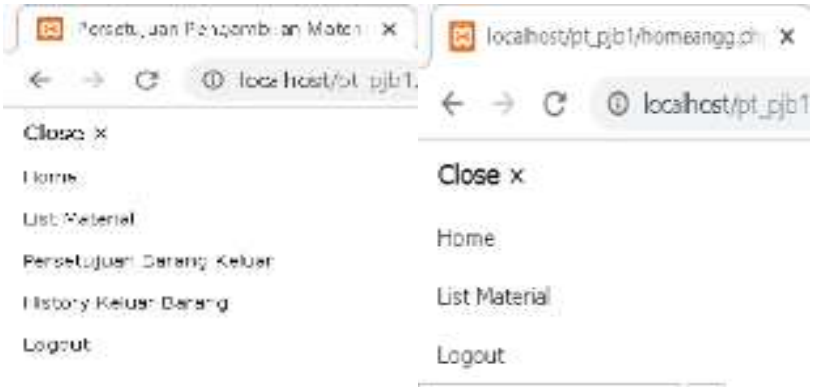

Gambar 14. Menu Utama Supervisior (Kiri) dan Anggota/Umum (Kanan)

\section{Kesimpulan}

Permasalahan yang terjadi pada gudang material return adalah sulitnya user dalam pengambilan material dikarenakan banyaknya barang yang masih belum terdata dan belum ada pemberian kode penempatan barang berdasarkan peraturan di PT ABC UP X. Selain itu proses administrasi untuk pengeluaran material return belum terintegrasi menggunakan sistem online sehingga user tidak memiliki data mengenai status dan jumlah material. Dalam menentukan prioritas penempatan material, didapati bahwa material mekanik memiliki prioritas nomor 1 dengan nilai 13,7; material instrumentasi memiliki prioritas nomor 2 dengan nilai 9; material listrik dengan nilai 7,8 dan material umum dengan nilai 6,5. Jika material ditata berdasarkan prioritas penempatan material, maka terjadi prosentase penurunan jarak sebesar $17 \%$. Allowance yang dibutuhkan di gudang return adalah minimal $4 \mathrm{~m}$. Perancangan sistem informasi pergudangan memiliki 4 sistem dimana akan ada perbedaan menu yang diperuntukkan untuk admin, user, spv, dan anggota/umum,

\section{Daftar Pustaka}

Apple, James M, 1990, Tata Letak Pabrik dan Pemindahan Bahan. Edisi Ketiga .Bandung: ITB.

Noor, I. 2018. Peningkatan Kapasitas Gudang dengan Redesign Layout Menggunakan Metode Shared Storage. JURNAL JIEOM Vol, 1.

Purnomo Hari. 2004. Pengantar Teknik Industri. Yogyakarta: Graha ilmu

Putri, A. W., \& Marie, I. A. 2017. RANCANGAN PERBAIKAN TATA LETAK GUDANG BARANG JADI PRODUK STAMPING PARTS PADA PT. CSM BERDASARKAN METODE FUZZY SUBTRACTIVE CLUSTERING ALGORITHM. Jurnal Ilmiah Teknik Industri (Jurnal Keilmuan Teknik dan Manajemen Industri), 3(2).

Tompkins, J. A., dkk. 2010. Facilities Planning. Fourth Edition. New York, NY : John, Wiley Warman, John. 2004. Manajemen Pergudangan. Jakarta: Pustaka Sinar Harapan

Widodo, Lamto, dkk. 2013. Usulan Pernbaikan Rancangan Tata Letak Penyimpanan Bahan Baku Berdasarkan Kriteria Pemakaian Bahan. Jurnal Al- Azhar Indonesia Seri Sains dan Teknologi. 2(2):71

William dan Sawyer. 2007. Using Information Technologi. Yogyakarta

Zaroni. 2015. Prinsip-prinsip Warehouseing. Jakarta:Supply Chain Indonesia 